Dwi Rahayu, Dalillah Razan, Annisa Rahayu P, Imam Ainuddin, Selvy Megira, Ria Andriani, Ade Pujianto, Ema Utami

\title{
Desain Visual Antarmuka Website E-kartu nikah
}

\section{Visual Interface of E-Marriage Card Website Design}

\author{
Dwi Rahayu * ${ }^{1}$, Dalillah Razan $\mathbf{S}^{2}$, Annisa Rahayu $\mathbf{P}^{3}$, Imam Ainuddin $\mathbf{P}^{4}$, \\ Selvy Megira ${ }^{5}$, Ria Andriani ${ }^{6}$, Ade Pujianto ${ }^{7}$, Ema Utami $^{8}$ \\ ${ }_{1,2,3,4,6,7,8}$ Magister Teknik Informatika Universitas AMIKOM Yogyakarta, \\ ${ }^{5}$ AMIK Lembah Dempo, Palembang \\ dwirahayu.giman@gmail.com¹,dalilah.s@ students.amikom.ac.id ${ }^{2}$,
}

ade.pujianto@students.amikom.ac.id ${ }^{3}$, ainudinimam@gmail.com ${ }^{4}, \underline{\text { selvymegi96@ gmail.com }}{ }^{5}$,

ria.an@ students.amikom.ac.id ${ }^{6}, \underline{\text { ade.pujianto@ }}_{\text {students.amikom.ac.id }}{ }^{7}, \underline{\text { emma@nrar.net }^{8}}$

\begin{abstract}
Abstrak
Pernikahan yang sah secara agama dan yang tercatat resmi oleh pemerintah ditunjukkan dengan bukti kepemilikan buku nikah. Buku nikah menjadi salah satu dokumen pribadi yang digunakan untuk berbagai kepengurusan dan birokrasi pemerintahan seperti pembuatan pasport, tunjangan keluarga, asuransi dan urusan lainnya. Efektifitas dari segi keamanan maupun dalam penggunaan buku bikah sangatlah perlu untuk ditingkatkan. E-kartu nikah merupakan elektronik buku nikah yang dilengkapi dengan teknologi mikrochip sebagai media penyimpan data dan sebagai kemanan data yang tersimpan didalamnya. Informasi yang tersimpan didalamnya adalah informasi yang ada pada buku nikah. Kartu pintar E-kartu nikah terintegrasi dengan website, dimana pengguna dapat mengakses infromasi menggunakan nomor seri yang ada pada E-kartu nikah. Teknologi microchip yang tertanam pada kartu mempermudah dan mempercepat proses verfikasi data apabila suatu kepengurusan menggunakan alat bantu card reader. Sasaran pengguna website E-kartu nikah mencangkup semua golongan dengan rentang usia diatas 19 tahun. Pada penelitian ini fokus pada perancangan antarmuka website dengan memperhatikan aspek elemen-elemen dasar desain visual pada desain antarmuka dengan menggunakan model prtotipe jenis evolutionary. Hasil akhir dari penilitian ini adalah rancangan kartu pintar terbuat dari plastik dan berukuran 5,4 $x$ $8,6 \mathrm{~cm}$ dan website sebagai portal akses E-kartu nikah.
\end{abstract}

Kata kunci-E-kartu nikah, smart card, buku nikah, desain visual.

Abstract

Legally registered marriages are shown by ownership of marriage books as proof. The marriage book becomes one of the personal documents used for various stewardship and government bureaucracy such as the manufacture of passports, family allowances, insurance and other affairs. Effectiveness in terms of security and in the use of books of marriage is very necessary to be improved. E-marriage card is an electronic marriage book which is equipped with microchip technology as data storage media and as security of data stored. In the information stored that is the information contained in the marriage book. Smart E-card, smart card is integrated with the website, where users can access the information using the serial number on the E-marriage card. Microchip technology embedded in the card simplify and speed up the process of data verfication when a stewardship using card reader tool. The target for users of website E-marriage card includes all groups with age range above 19 years. In this research focus on designing website interface by paying attention aspect element of visual design at interface design by using evolutionary type of prtotype model. The final result of this research is the plastic card design and measuring $5.4 \times 8.6 \mathrm{~cm}$ and the website as the E-card access portal of marriage. 
Keywords-E-Nikah Card, smart card, marriage book, visual design.

\section{PENDAHULUAN}

Buku nikah merupakan bukti pernikahan yang sah secara agama dan negara yang wajib dimiliki oleh setiap individu yang telah menikah. Di Indonesia, buku nikah menjadi satusatunya bukti pernikahan sah yang harus dibawa disetiap saat sebagai syarat dalam urusan birokrasi maupun kepentingan pribadi, sehingga hal ini lah yang membuat buku nikah menjadi sesuatu yang penting. Namun, bentuk fisik dari buku nikah yang berupa buku yang terbuat dari lembaran-lembaran kertas di setiap halamannya mengharuskan pemilik untuk menggunakan dan menyimpannya dengan baik, karena apabila penyimpanan dan penggunaannya kurang baik maka bukan tidak mungkin buku nikah akan mengalami kerusakan dan bahkan hilang.

Kerusakan buku nikah seringkali terjadi dikarenakan kelalaian dari pemiliknya seperti robek, terkena air, terbakar dan lainnya. Sedangkan buku nikah yang hilang atau rusak tidak dapat dicetak kembali dengan tampilan yang sama seperti buku nikah asli, melainkan nomor seri buku nikah berubah dan ada tanda bahwa buku nikah tersebut merupakan duplikasi. Berdasarkan data yang didapatkan, kasus lain yang sering terjadi terkait dengan buku nikah yaitu adanya pemalsuan buku nikah. Meskipun pemerintah telah mengupayakan untuk meningkatkan keamanan, pemalsuan buku nikah masih sering terjadi yang dilakukan berdasarkan alasan-alasan seperti kepentingan pribadi, hilangnya dokumen-dokumen prasyarat pengajuan buku nikah, dan pernikahan dibawah umur. Oleh karena itu, diperlukan adanya peningkatan keamanan terhadap buku nikah agar kerusakan, kehilangan dan pemalsuan buku nikah dapat diminimalkan.

E-kartu nikah merupakan sebuah kartu sebagai identitas dari pasangan yang telah menikah. Pada E-kartu nikah ini juga dilengkapi dengan chip yang berfungsi untuk mengamankan kartu dari adanya pemalsuan. E-kartu nikah hanya dapat dimiliki oleh pasangan yang telah menikah secara resmi tercatat di pemerintahan dengan mendaftarkan diri terlebih dahulu. Bagi pasangan yang telah mendaftar dan lolos pada tahap verifikasi identitas buku nikah, maka Kemenang akan memerintahkan KUA untuk menerbitkan kartu E-kartu nikah. Masing-masing individu akan mendapat kartu E-kartu nikah dengan nomor seri yang sama, namun warna dan kode pada digit pertama sebelum nomor seri mempunyai perbedaan antara suami dengan istri. Proses pendaftaran E-kartu nikah ini dapat dilakukan baik secara langsung dengan mengajukan permohonan pada KUA setempat ataupun melalui website E-kartu nikah.

Website E-kartu nikah merupakan website yang dibuat untuk memberikan kemudahan bagi pihak KUA dan juga pengguna dalam mendaftar dan mengajukan pengaduan yang terkait dengan Kartu E-Nikah. Desain antarmuka pada website ini dirancang sesuai dengan kebutuhan pengguna dengan menerapkan berbagai prinsip-prinsip desain antarmuka seperti yang telah dikemukakan pada penelitian perancangan Grapichal User Interface "Si Jambe" sebagai Media Pembelajaran di Jambi, yang membahas tentang perancangan aplikasi Si Jambe, dengan menggunakan prinsip graphical user interface menurut Deborah J Mayhew [1]. Namun pada penelitian tersebut, prinsip desain user interface yang diterapkan pada desain aplikasi nya hanya menggunakan satu prinsip saja, yaitu user familiarity sehingga desain aplikasi yang dirancang tidak memiliki kelebihan berdasarkan prinsip lainnya. Sedangkan pada penelitian ini, selain menggunakan prinsip user familiarity, prinsip-prinsip user interface lainnya juga digunakan sebagai acuan dalam merancang desain website E-kartu nikah.

Selain menerapkan prinsip-prinsip user interface, dalam merancang desain antarmuka suatu website juga harus memperhatikan aspek kenyamanan dari pengguna ketika menggunakan website tersebut, seperti yang dikemukakan pada penelitian Design of the User Experience for Personalized Mobile Services yang meneliti tentang proses perancangan desain pada tampilan mobile dengan menggunakan salah satu metode dalam desain yaitu co-design yang diintregrasikan kedalam HCI. Tujuan utama dari artikel ini adalah untuk mendemonstrasikan peran yang dimainkan oleh co-design dalam desain layanan mobile yang berpusat pada 
pengguna untuk para penonton di acara olahraga besar. Kelompok pengguna tertentu dalam penelitian ini adalah pengguna China, yang memiliki karakteristik khusus yang menghadirkan tantangan khusus untuk co-design. Penelitian ini menunjukkan bahwa desain antarmuka memiliki pengaruh terhadap kenyamanan pengguna [2]. Perbedaan yang ada pada penelitian tersebut dengan penelitian ini yaitu terdapat pada sasaran penggunanya. Pada penelitian ini sasaran penggunanya adalah pasangan yang telah menikah dan pihak KUA, sehingga tantangan yang muncul adalah bagaimana merancang desain antarmuka website E-Kartu Nikah dan kartu E-Nikah agar sesuai dengan sasaran penggunanya, seperti yang dipaparkan pada penelitian A Review on User Interface Design Principles to Increase Software Usability for Users With Less Computer Literacy. Dalam penelitian tersebut disebutkan bahwa terdapat beberapa jenis pengguna dari komputer yaitu para orang tua yang kurang menguasai komputer, anak-anak sebagai pemula, dan pengguna dengan kelainan mental maupun fisik. Beberapa jenis pengguna tersebut merupakan fokus dari penelitian yang akan menghasilkan kesimpulan mengenai desain antarmuka seperti apa yang paling dibutuhkan oleh pengguna dengan menggunakan prinsipprinsip yang dapat memecahkan masalah usability [3]. Berdasarkan penelitian-penelitian terdahulu yang telah dipaparkan di atas, dapat disimpulkan bahwa dalam merancang desain antarmuka sebuah website harus memenuhi prinsip-prinsip dasar desain antarmuka website dengan elemen-elemennya yang sesuai dengan sasaran agar kebutuhan setiap pengguna dapat terpenuhi sehingga dapat meningkatkan kepuasan pengguna.

\section{METODE PENELITIAN}

Prototyping merupakan teknik pengembangan sistem untuk menggambarkan system, sehingga pengguna atau pemilik sisitem mempunyai gambaran pengembangan sistem yang akan dilakukan. Dalam pengembangan sistem informasi, prototype sering diwujudkan dalam bentuk user interface program aplikasi dan contoh-contoh reporting yang akan dihasilkan, sehingga dengan demikian pengguna sistem akan mempunyai gambaran tentang sistem yang akan digunakan nanti.

Pada penelitian ini menggunakan prototype model evolutionary, dimana prototype secara terus menerus dikembangkan hingga prototype tersebut memenuhi fungsi dan prosedur yang dibutuhkan oleh sistem. Adapun langkah-langkah evolutionary prototype seperti yang ditunjukan pada gambar 1 .

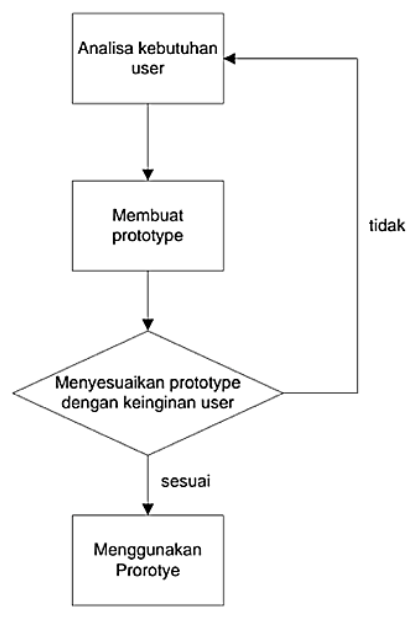

Gambar 1. Evolutionary Prototype

Berikut langkah-langkah Evolutionary Prototype:

a. Analisis kebutuhan user, pengembang dan pengguna atau pemilik sistem menjelaskan 
kepada pengembang tentang kebutuhan sistem yang diinginkan.

b. Membuat prototype, pengembang membuat prototype dari sistem yang telah dijelaskan oleh pengguna atau pemilik sistem.

c. Menyesuaikan prototype dengan keinginan user, pengembang mananyakan kepada pengguna atau pemilik sistem tentang prototype yang sudah dibuat, apakah sesuai atau tidak dengan kebutuhan sistem.

d. Menggunakan prototype, sistem mulai dikembangkan dengan prototype yang sudah dibuat [4].

Pada analisis kebutuhan user dilakukan dengan melalui observasi dari berita diberbagai media yang terbit dari tahun ke tahun adanya kasus pemalsuan buku nikah yang disebabkan oleh berbagai faktor, seperti pemohon tidak memilki kelengkapan dokumen prasayarat pada suatu ke[engrurusan, pernikahan dibawah tangan, pernikahan berbeda kewarganegaraan, dan pernikahan dini. Seperti pada kasus yang dimuat berita tempo, bahwa Inspektur Jenderal Kementerian Agama M. Jasin mengatakan kasus pemalsuan buku nikah di Cakung, Jakarta Timur, bukan hal yang baru. Menurut dia, pada 2014, Kementerian Agama menemukan buku nikah palsu yang akan dikirim ke luar negeri. Menurut Jasin, pemalsuan terjadi karena desain di buku nikah mudah ditiru selain itu pemalsuan buku nikah terjadi juga karena kurangnya sosialisasi bukti pernikahan itu kepada masyarakat.Sebelumnya, Kepolisian Resor Metro Jakarta Timur membongkar jaringan pemalsu buku nikah dan akta cerai. Seorang pria berinisial N, 50 tahun, dibekuk polisi di rumahnya di Cakung, Jakarta Timur, pada Selasa, 26 Mei 2015. Dari tangannya, polisi menyita 65 stempel Kementerian Agama dan 64 buku nikah palsu. Adapun motif tersangka melakukan pemalsuan buku nikah disebabkan mampu mengumpulkan omzet hingga 5 juta/bulan [5].

Ditemukan pada penelitian "Peran Pemerintah Daerah (Desa) Dalam Menangani Maraknya Fenomena Pernikahan Dini Di Desa Plosokerep Kabupaten Indramayu" pada tahun 2016 yang ditulis oleh Martyan Mita Rumekti dan V. Indah Sri Pinasti, mahasiswa Universitas Negeri Yogyakarta jurusan pendidikan sosiologi, mengatakan bahwa pandangan masyarakat tentang pernikahan dini di Desa Plosokerep adalah mempunyai pandangan yang positif karena hal tersebut sudah biasa terjadi. Peran pemerintah sangat berpengaruh terhadap kesejahteraan masyarakatnya. Pemerintah desa tentunya sangat menyayangkan anak-anak yang masih diusia sekolah harus memilih untuk menikah karena seharusnya anak-anak tersebut mendapatkan pendidikan yang layak dan harus melanjutkan pendidikan yang lebih tinggi. Hal tersebut memicu pemerintah desa untuk mengatasi atau meminimalisir terjadinya pernikahan dengan cara, tahap awal dinasehati yang dilakukan oleh pegawai pencatat pernikahan, memotivasi orang tua untuk melanjutkan pendidikan yang lebih tinggi bagi anaknya, ditangguhkan buku nikah, memperketat aturan undang-undang perkawinan beserta sanksinya [6]. Adanya wewenang kantor urusan agama menagguhkan buku nikah bagi pelaku pernikahan dini, diharapkan hal tersebut dapat menekan angka pernikahan dini, akan tetapi justru timbul pemalsuan buku nikah.

Selanjutnya, melakukan survei ke kantor urusan agama Depok, Sleman Yogyakarta. Pada tahap survei yakni wawancara dengan kepala kantor urusan agama untuk mengumpulkan informasi mengenai pelayanan permohonan buku nikah dan proses mendapatkan kembali buku nikah jika terjadi kehilangan atau kerusakan, tercatatat sebanyak 2013 pemohon, keterangan alas an pemohon mengajukan duplikat buku nikah seperti yang ditunjukan pada gambar 2 , dibawah ini. 


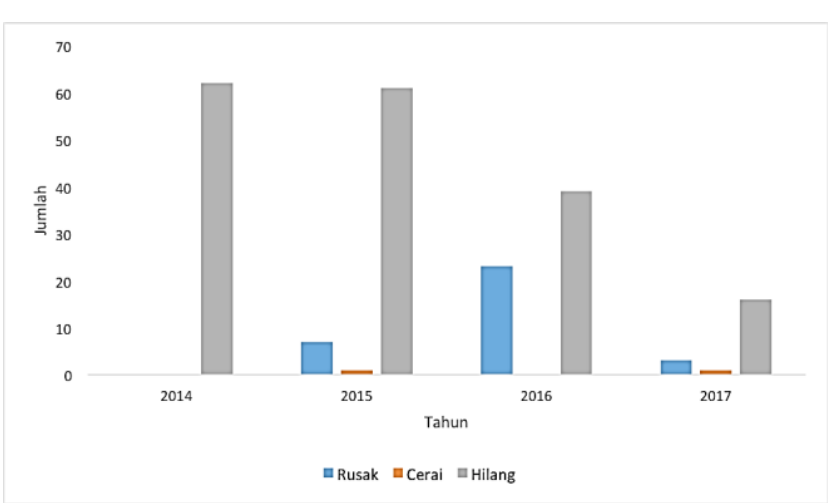

Gambar 2. Grafik pengajuan buku nikah

Adapun petunjuk penerbitan buku nikah ulang apabila buku nikah hilang yaitu, pemohon harus membuat surat keterangan kehilangan dari pihak kepolisian terlebih dahulu, kemudian mengajukan surat pemohon ke kantor urusan agama. Apabila terjadi kerusakan, pemohon wajib membawa bukti kerusakan, kemudian buku nikah yang telah rusak akan ditarik oleh kantor urusan agama. Buku nikah yang dicetak ulang tidak bisa sama dengan buku nikah asli, melainkan terdapat tanda duplikasi seperti yang ditunjukkan pada gambar 3, dan nomor seri buku nikah pun berbeda dengan sebelumnya.

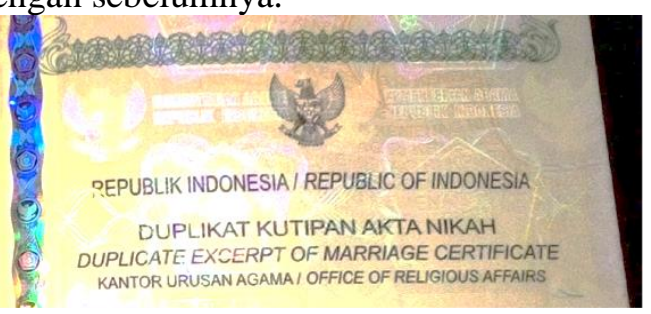

Gambar 3. Data pengajuan ganti buku nikah

Kepala kantor urusan agama depok, mengemukakan bahwa masalah pemalsuan buku nikah pun masih menjadi kasus yang masih belum bisa dihilangkan, meskipun kemanan buku nikah terus ditingkakan. Hal lain yang kerap terjadi terkait dengan buku nikah yakni, perizinan dalam berbagai urusan atau pelayanan yang membutuhkan identitas pengenal pasangan resmi suami istri, seperti pada reservasi hotel. Beberapa hotel di Indonesia sudah menerapkan hal tersebut. Seringkali terjadi masalah pasangan suami istri harus memesan kamar terpisah karena tidak membawa buku nikah sebagai bukti pasangan resmi. Adapun penggunaan buku nikah palsu untuk kepentingan pribadi seperti yang termuat pada media kbr.id memuat berita Muhammad Atho'illah Muslim menuturkan biasanya buku nikah palsu digunakan karena berbagai faktor. Paling banyak untuk sarana poligami yang belum mendapatkan izin dari istri pertama. Selama masyarakat menggunakan jalur resmi pernikahan, hampir pasti terhindar dari buku nikah palsu. Sebelumnya, Polres Rembang menangkap seorang pria yang menggunakan buku nikah palsu, untuk sarana berpoligami. Pelaku mengatasnamakan nama sebuah daerah di Semarang. Polisi kini mendalami pembuat buku nikah palsu tersebut, karena disinyalir banyak menyebar ke daerah lain [7].

Melihat dari hasil observasi dan survei di kantor urusan agama, maka dilakukan identifikasi masalah seperti yang ditunjukkan pada tabel 1, untuk mengetahui aspek yang perlu dirancang sesuai dengan kebutuhan..Berdasarkan permasalahan buku nikah yang kerap hilang, rusak, ataupun tertinggal, oleh karena itu perlu adanya inovasi buku nikah berukuran kecil yang praktis masuk dalam dompet. Kartu nikah berbahan dasar plastik agar meminimalisir kerusakan akibat air atau kelalaian pemilik seperti sobek, atau kotor. Kartu nikah tidak hanya menjadi dokumen tambahan, tetapi dapat menyimpan data yang ada pada buku nikah. Penyimpanan data yang dapat diterapkan pada elektronik kartu nikah yaitu dengan menerapkan teknologi 
microchip. Teknologi microchip tidak hanya untuk meyimpan data melainkan mejadi pengaman data yang ada didalamnya. Hanya atas izin pemilik kartu yang dapat mengakses data pada microchip tersebut.

Tabel 1. Identifikasi masalah

\begin{tabular}{|c|c|c|c|c|}
\hline No. & Masalah & Sebab & Akibat & Solusi \\
\hline 1 & $\begin{array}{l}\text { Kehilangan atau } \\
\text { kerusakan buku } \\
\text { nikah }\end{array}$ & $\begin{array}{l}\text { Kelalaian pemilik ataupun } \\
\text { penyimpanan jangka panjang. }\end{array}$ & $\begin{array}{l}\text { Tidak bisa mendapatkan buku } \\
\text { nikah yang sama, melainkan } \\
\text { duplikasi dari buku nikah. }\end{array}$ & $\begin{array}{l}\text { Elektronik buku nikah (E-kartu } \\
\text { nikah) dapat digunakan sebagai } \\
\text { pengganti buku nikah }\end{array}$ \\
\hline 3 & $\begin{array}{l}\text { Kesalahan input } \\
\text { data secara } \\
\text { manual. }\end{array}$ & $\begin{array}{l}\text { Petugas ingin menyalin isi } \\
\text { dalam buku nikah untuk } \\
\text { keperluan beberapa } \\
\text { keperluan. }\end{array}$ & $\begin{array}{l}\text { Penyalinan data memerlukan } \\
\text { waktu yang cukup lama. }\end{array}$ & $\begin{array}{l}\text { Menggunkan card reader untuk } \\
\text { membaca E-kartu nikah guna } \\
\text { memvalidasi data pasangan, atau } \\
\text { dengan cara memasukkan ID n pada } \\
\text { website E-kartu nikah. }\end{array}$ \\
\hline
\end{tabular}

\section{HASIL DAN PEMBAHASAN}

Desain visual berfokus pada estetika sebuah situs dan materi terkait dengan menerapkan gambar, warna, font, dan elemen lainnya secara strategis. Desain visual yang sukses tidak menghilangkan konten atau fungsi pada halaman. Melainkan warna meningkatkan maksud dengan melibatkan pengguna dan membantu membangun kepercayaan dan ketertarikan pada merek. Elemen dasar desain visual merupakan unsur dasar yang digabungkan untuk menciptakan desain visual [8]. Hasil akhir pada penelitian ini berupa kartu seperti E-KTP yang memiliki fungsi yang sama dengan buku nikah. E-kartu nikah dimiliki oleh masing pasangan dengan desain seperti pada gambar 4, dimana terdapat perbedaan pada warna latar belakang nomor seri. Nomor seri pasangan pun sama yang mmbedakan hanya pada kode 1 digit sebelum nomor seri.

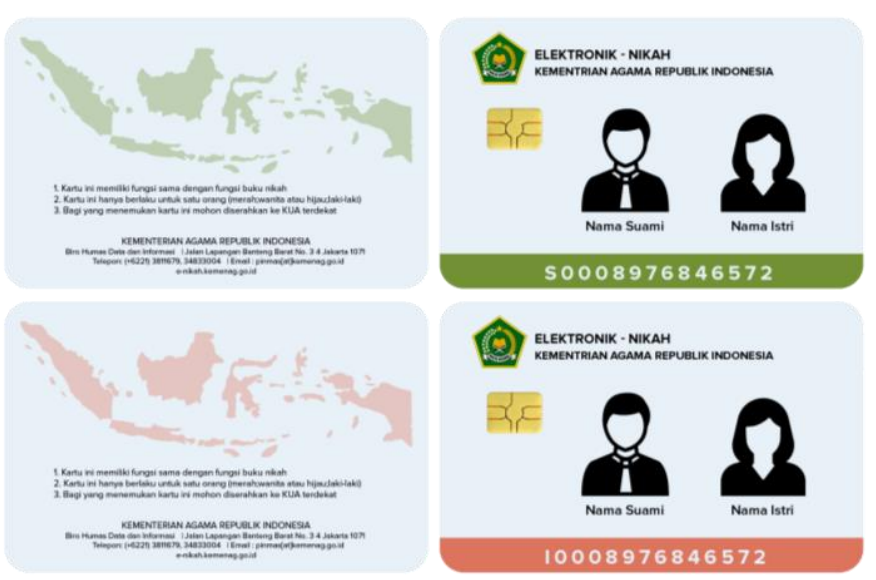

Gambar 4. Rancangan kartu

Selain estetika, penelusuran website terkait memilki pengaruh untuk menentukan waarna, jenis font, tata letak dan konsep. Website menjadi identitas suatu instansi sehingga perlu diperhatikan dalam menentukan konsep. Pengambilan konsep website dapat diambil dari logo atau brand terkait. Faktor lain yang harus diperhatikan adalah sasaran pengguna website, karena berguna atau tidaknya sebuah website tergantung dari kenyamanan pengguna. Sebuah website dapat dikatakan gagal apabila pengguna banyak yang beralih ke website atau media lain. Sasaran penggguna website E-kartu nikah yakni usia pernikahan berdasarkan undangundang yakni diatas 19 tahun.

Penelusuran website terkait pada penelitian ini, ditunjukkan pada gambar 5 yang merupakan salah satu website program Kemenag khususnya dalam hal pernikahan yaitu Simkah 
Online. Website simkah.kemenag.go.id merupakan sistem informasi berbasis website yang memberikan layanan untuk masyarakat mendaftar nikah secara online [9]. Pada website tersebut terdapat banyak fitur seperti jadwal akad, informasi pernikahan, galeri, forum, dan sosial media facebook dan youtube, dan lain-lain.

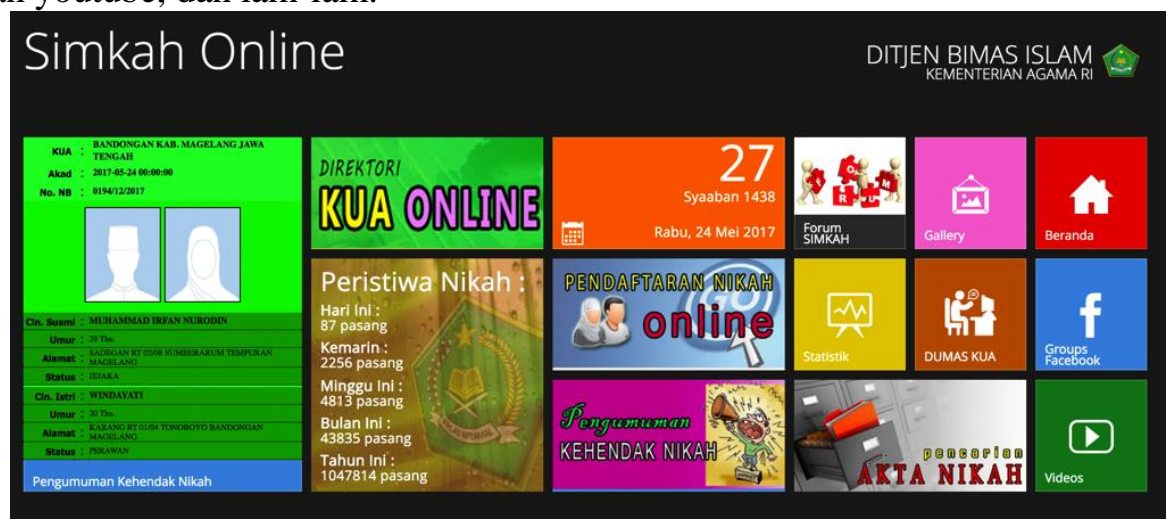

Gambar 5. Halaman beranda simkah online

Berdasarkan elemen dasar desain visual, evaluasi dari website simkah online sebagai berikut [8]:

a. Garis menghubungkan dua titik dan dapat digunakan untuk membantu menentukan bentuk, membuat divisi, dan menciptakan tekstur. Semua garis, jika lurus, memiliki panjang, lebar, dan arah. Sedangkan pada website Simkah garis yang digunakan tidak secara konsisten ada pada setiap bentuk, terlihat pada kotak menu dan font ada yang menggunakan garis tepi ada beberapa yang tidak menggunakan.

b. Bentuk adalah area mandiri. Untuk menentukan area, designer menggunakan garis, perbedaan nilai, warna, dan / atau tekstur. Setiap benda tersusun dari bentuk. Ukuran bentuk satu sama lain tidak konsisten, sehingga memberi kesan tidak beraturan. Dan ukuran gambar maupun font seperti tidak simestris.

c. Pilihan dan kombinasi palet warna digunakan untuk membedakan item, menciptakan kedalaman, menambahkan penekanan, dan / atau membantu mengatur informasi. Teori warna meneliti bagaimana berbagai pilihan secara psikologis mempengaruhi pengguna. Pilihan dan kombinasi palet warna pada website Simkah Online terlalu kontras, seperti tidak ada keselarasan warna. Warna yang digunakan pada font bertolak belakang dengan latar belakang, sehingga terkesan warna bertabrakan dan sulit terbaca.

d. Tekstur mengacu pada bagaimana permukaan terasa atau dirasakan. Dengan mengulangi sebuah elemen, sebuah tekstur akan tercipta dan sebuah pola terbentuk. Bergantung pada bagaimana tekstur diterapkan, teknik ini dapat digunakan secara strategis untuk menarik atau mencegah perhatian. Pada website Simkah Online penggunaan simbol tidak konsisten, ada yang disimbolkan dengan ikon dan ada yang menggunakan gambar ataupun logo. Penempatan dan ukuran font menumpuk pada simbol.

e. Tipografi mengacu pada font mana yang dipilih, ukuran, keselarasan, warna, dan jaraknya. Pemilihan jenis font terlalu banyak, ukuran maupun warna pada font bertolak belakang dengan warna latar belakang, sehingga terkesan menumpuk dan sulit untuk dibaca.

f. Form yang dibuat dengan menggabungkan dua atau lebih bentuk dan dapat dibedakan dari aspek nada, tekstur, dan warna bentuk.

Dari hasil evaluasi elemen dasar visual yang digunakan pada website Simkah Online, dapat disimpulkan bahwa website E-kartu nikah tidak mengambil tema atau nuansa yang digunakan simkah online. Akan tetapi tetap mengambil warna primer yang digunakan pada logo Kemenag. Website E-kartu nikah merupakan program pelengkap yang menjadi bagian dari program Kemenag. Dari aspek tipografi website E-kartu nikah menggunakan font Proxima 
Nova Regular untuk informasi yang bersifat tegas dan Proxima Nova Light untuk kalimat keterangan atau informasi kedua. Proxima Nova yang merupakan jenis font sederhana namun resmi. Warna yang digunakan dalam website ini terdapat 4 warna utama dan terdapat warna pendukung yaitu merah sebagai warna umum yang menandakan peringatan atau petunjuk yang harus segera diperbaiki [10].

a. Hijau (\#336633) paling sering dikaitkan dengan alam. Ini adalah warna yang menenangkan yang melambangkan pertumbuhan, Kesegaran, dan harapan. Ada sedikit keraguan mengapa warnanya begitu terkait erat dengan lingkungan perlindungan. Secara visual, hijau jauh lebih mudah pada mata, dan jauh lebih dinamis daripada kuning, Oranye, atau merah Meski banyak desain website menggunakan daya tarik hijau terhadap selera pengunjung, Warna hijau adalah serbaguna yang juga bisa mewakili kekayaan, stabilitas, dan edukasi.

b. Kuning (\#ffcc33) adalah warna yang aktif, memberi kesan kegembiraan, terang, cerah, bersinar, ketegasan. Menstimulus pandangan mata seperti warna jingga. Dari sisi kelembagaan: Kuning menunjukkan optomism lembaga atau perusahaan.

c. Abu- abu (\#cccccc) bermakna serius, bisa diandalkan dan stabil. Abu - abu dalam lembaga bermakna warna netral yang menunjukkan keseimbangan. Warna yang tenang seperti air memberikan kesan keseimbangan.

d. Penggunaan putih (\#fffff) benar-benar membantu mempromosikan gagasan bahwa ini adalah kekuatan bersih. Dalam budaya Barat, putih dianggap sebagai warna kesempurnaan, cahaya, dan kemurnian.

Kombinasi keempat warna memiliki makna gabungan yaitu, suatu harapan yang bisa diandalkan dan dapat dipercaya untuk mendukung program kemajua negara demi mencapai kesejahteraan rakyat Indonesia. Tampilan antarmuka website secara keseluruhan dibuat mengikuti menggunakan elemen dasar desain visual.

Sebelum mengimplementasikan desain antarmuka website, langkah pertama yang dilakukan adalah dengan merancang struktur website. Struktur website merupakan kerangka dimana halaman-halaman website disusun dan dihubungkan satu dengan yang lainnya. Pada website ini, struktur menu website yang dirancang memiliki dua level kedalaman dengan tiga lapisan. Struktur ini dirancang agar website dapat dengan mudah ditelusuri oleh pengguna, yang ditunjukkan pada gambar 6 dan struktur menu pengguna untuk admin yang ditunjukkan pada gambar 7. Berikut ini merupakan struktur menu bagi user dan admin pada rancangan antarmuka website E-kartu nikah:

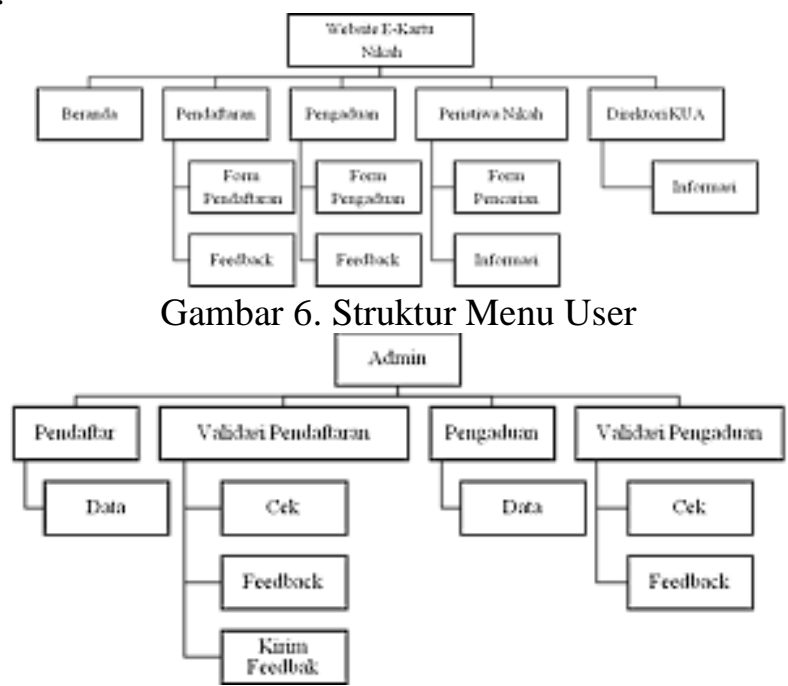

Gambar 7. Struktur Menu Admin

Antarmuka adalah bagian dari studi yang disebut Interaksi Manusia Komputer yang merupakan studi, perencanaan, dan desain bagaimana orang dan komputer bekerja sama sehingga kebutuhan seseorang puas dengan cara yang paling efektif [11]. Pengguna terbiasa 
dengan elemen user interface yang bertindak dengan cara tertentu, sehingga sebuah user interface harus konsisten dan mudah ditebak dalam pilihan dan tata letaknya. Cara terbaik untuk merancang user interface yaitu dengan mengetahui sasaran pengguna, termasuk memahami tujuan, keterampilan, preferensi, dan kecenderungan pengguna dengan cara menyajikan antarmuka sederhana, secara startegis menggunakan warna dan tekstur yang konsisten, menggunakan tipografi yang jelas dan sesuai dengan tema website, efisiensi tata letak layout [12]. Berikut rincian elemen visual desain yang diterapkan pada halaman-halaman antarmuka pada gambar $8,9,10,11,12,13$.

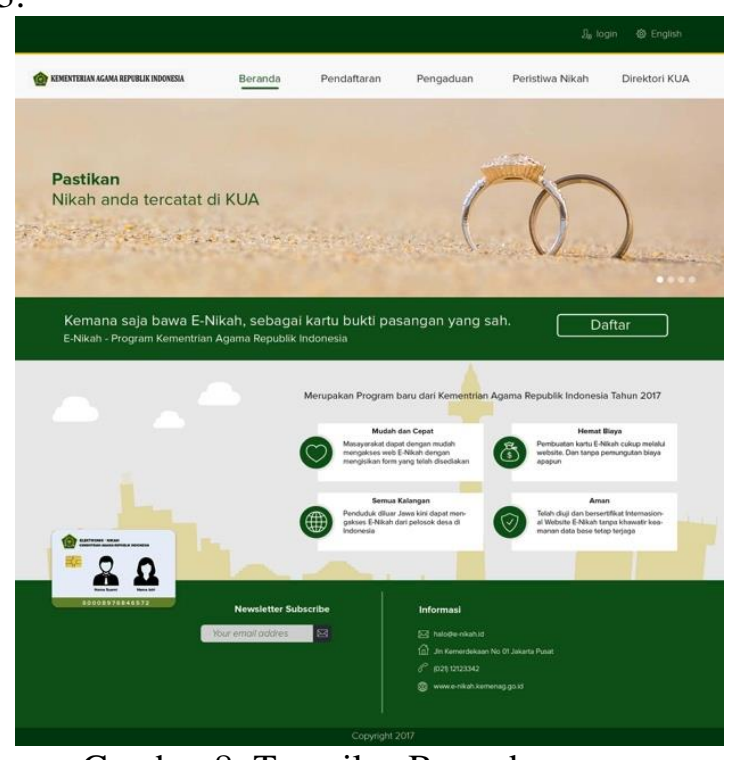

Gambar 8. Tampilan Beranda

Tampilan antarmuka beranda atau halaman pertama yang ditunjukkan pada gambar 8 , penggunaan garis berwarna kuning pada header, garis berwarna hijau dibawah menu yang menunjukkan pengguna sedang berada dihalaman tersebut, garis pada bagian footer sebagai pembatas konten. Kekurrangan pada tampilan ini footer terlihat terlalu luas, ada baiknya apabila diperkecil sehingga bisa ruang unutuk kontent lebih luas.

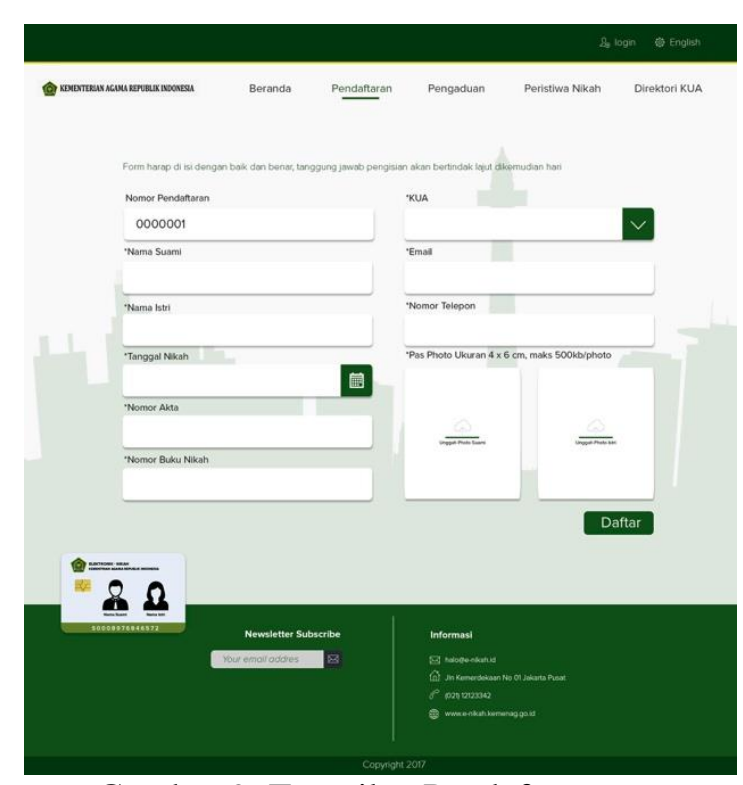

Gambar 9. Tampilan Pendaftaran 
Tampilan form pendaftaran seperti yang ditunjukkan pada gambar 9, dilengkapi dengan bentuk persegi panjang dengan siku tumpul pada semua text filed dan button daftar, pada text field Newsletter Subsscribe untuk menuliskan email. Ikon pada button merupakan bentuk sebagai simbol yang membantu menyampaikan content, seperti ikon kalender yang menunjukkan bahwa pengguna dapat memilih tanggal tanpa harus mengetik manual. Ikon pada button combo box yang memiliki fungsi pilihan data, sehingga pengguna tidak perlu menulis sampai dengan selesai karna akan muncul saran data yang mengandung huruf yang dimasukkan pengguna. Hal tersebut dapat meminimalisir kesalahan format kepenulisan. Kelemahan pada tampilan ini, dalam penggunaan tanda bintang (*). Pada umumnya banyak ditemukan tanda * berada dibelakang kalimat dan terdapat keterangan dibagian bawah form.

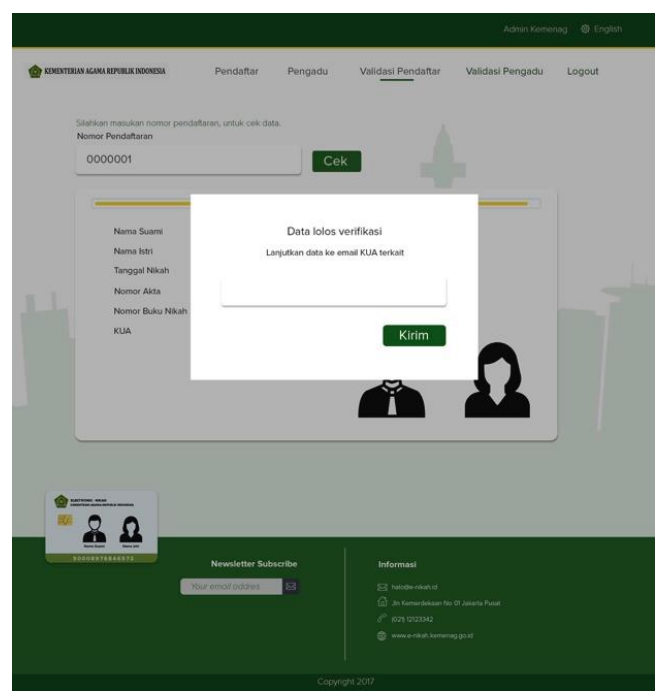

Gambar 10. Tampilan Validasi

Pemilihan kombinasi palet warna digunakan untuk membedakan item, terdapat kontras warna seperti yang ditunjukkan pada gambar 10, terdapat warna sedikit gelap tapi tidak menutupi laman utama, berguna untuk menggiring pengguna fokus pada informasi yang dimaksud. Kelemahan pada tampilan ini warna pop up kotak dialog kurang memiliki kontras dengan bentuk text filed, sehingga teksttur yang dihasilkan seperti sekilas sama, hal ini perlu diperhatikan, khususnya untuk pengguna yang memiliki penglihatan yang kurang baik.

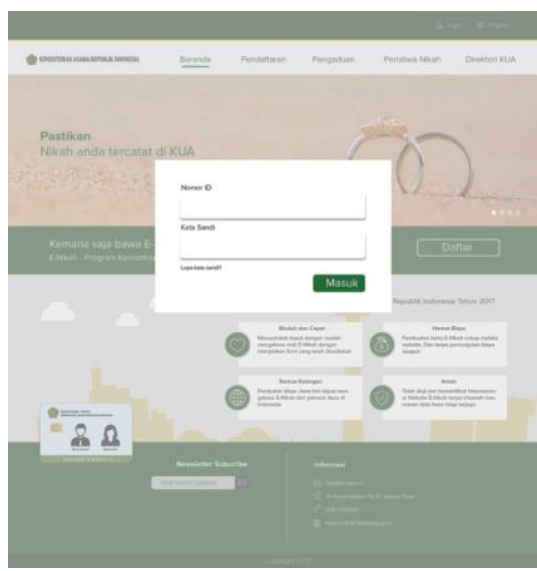

Gambar 11. Tampilan Login

Ukuran font yang berbeda, "lupa kata sandi?" lebih kecil daripada "Nama ID dan Kata Sandi" yang ditunjukan pada gambar 11. Hal tersebut untuk membedakan informasi utama dan informasi pelengkap yang disampaikan pada kotak dialog tersebut. Warna font yang digunakan 
menyesuaikan warna latar belakang, seperti pada tombol button "Masuk". Hal tersebut bertujuan untuk dapat terbaca dengan jelas dan memberi kesan pop up. Kelemahan pad tampilan ini, tidak ada perbedaan yang jelas antara login untuk admin atau user. Dari website yang umum dijumpai saat ini pada tampilan login disamping terdapat tombol "masuk" dan "lupa kata sandi", juga terdapat menu "pendaftaran".

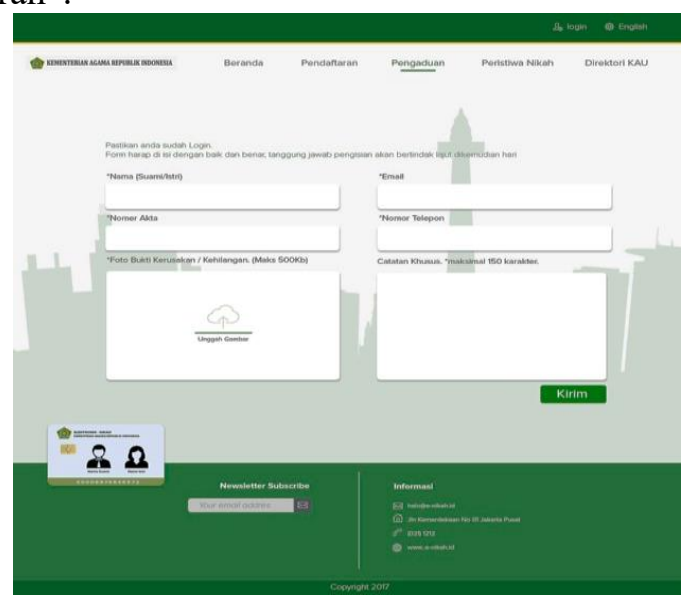

Gambar 12. Tampilan Pengaduan

Ditunjukkan pada gambar 12, form dibuat dari bentuk yang dikombinasikan dengan shadow sebagai gradasi pemisah dengan latar belakang. Gradasi warna menciptakan tekstur desain yang senada tidak terlalu kontras dengan latar belakang. Dan Teks yang berada disetiap text field berwarna lebih terang dibandingkan dengan warna teks petunjuk pada bagian atas.

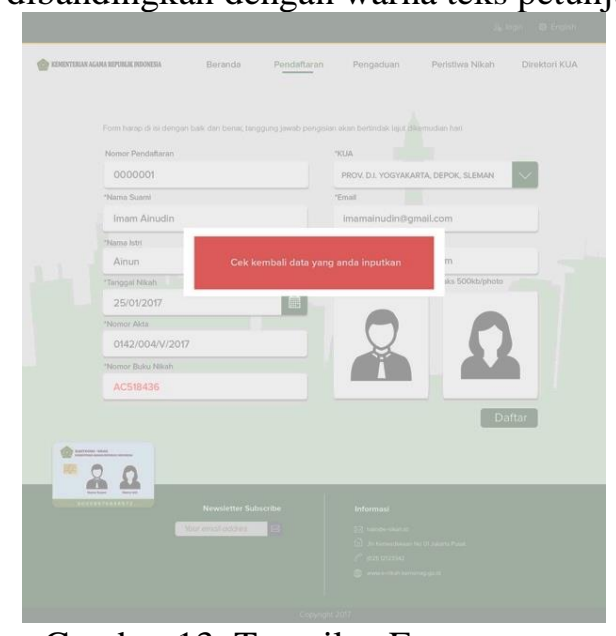

Gambar 13. Tampilan Error

Kesalahan pengguna dalam melakukan input data seringkali terjadi, untuk meminimalisir kesalahan data atau fomat yang masuk, maka terdapat peringatan eror yang ditandai font menjadi berwarna merah dan muncul pop up teks peringatan seperti yang ditunjukkan pada gambar 13.

\section{KESIMPULAN}

Pada penelitian ini sampai pada prototipe desain, belum sampai kepada testing website. Perancangan website didasarkan dari hasil evaluasi pada website simkah online yang kemudian dilakukan perancangan antarmuka dengan menganut prinsip dan elemen dasar antarmuka. Website merupakan identitas suatu istansi, pemilihan warna utama hijau pada website E-kartu nikah diambil dari konsep logo Kemenag. Font yang digunakan merupakan jenis font resmi dan 
sederhana yang mencerminkan intansi pemerintahan. Tata letak menu dan form dirancang berdasarkan pengamatan website dari program-program kementrian agama.

\section{SARAN}

Sebaiknya dilakukan penelusuran website terkait lebih dari satu sebelum dilakukan perancangan antarmuka website. Dalam proses penentuan konsep calon pengguna sebaiknya terlibat, hal ini untuk meminimalisir kesalahan atau ketidaktepatan desain yang berpangaruh terhadap kenyamanan pengguna.

\section{DAFTAR PUSTAKA}

[1] Khairurrizqi, Aris Rahmansyah, Teddy Hendiawan, 2015, Perancnagan Grapichal User Interface "Si Ajmbe" sebagai Media Pembelajaran di Jambi, Bandung.

[2] Sun, X., dan May, A., 2014, Design of the User Experience for Personalized Mobile Services, International Journal of Human Computer Interaction, Vol. 5, Ed. 2, hal 21-39.

[3] Darejeh, Ali, dan Singh, Dalbir, 2013, A Review on User Interface Design Principles to Increase Software Usability for Users With Less Computer Literacy, Journal of Computer Science, Vol. 9, Ed. 11, http://www.thescipub.com/jcs.toc.

[4] Sri Mulyani, 2016, Metode Analisis dan Perancangan Sistem, Edisi Kedua, Cetakan Ke1, Bandung: Abdi Sitematika, pp 27-28.

[5] https://m.tempo.co/read/news/2015/06/03/064671665/ini-penyebab-banyaknyapemalsuan-buku-nikah, diakses tanggal 8 juni 2017.

[6] Martyan, Mita, Rumekti , V. Indah, Sri, Pinasti, 2016, Peran Pemerintah Daerah (Desa) Dalam Menangani Maraknya Fenomena Pernikahan Dini Di Desa Plosokerep Kabupaten Indramayu, Jurnal Pendidikan, Universitas Negeri Yogyakarta.

[7] http://kbr.id/10-2016/poligami_jadi_alasan_palsukan_buku_nikah/86024.html, diakses tanggal 8 juni 2017.

[8] Peter, Morville, Louis, Rosenfeld's, 2007. Information Architecture for the World Wide Web: Designing Large-Scale Web Sites, O'Reilly Media, Amerika.

[9] http://simkah.kemenag.go.id/index.php, diakses tanggal 5 Juni 2017.

[10] Jasson Beaird, 2010, The Principles of Beautiful Web Design, SitePoint by Ltd, Kanada.

[11] Wilbert O. Galitz, 2007, The Essential Guide to User Interface Design: An Introduction to GUI Design Principles and Techniques, Robert Ipsen, Amerika.

[12] Jesse James Garrett's, 2011, The Elements of User Experience: User-Centered Design for the Web and Beyond (2nd Edition), New Riders, Berkeley. 